\title{
Free amino acids in the xylem sap of pear trees during dormancy
}

\author{
Aminoácidos livres na seiva do xilema de pereiras durante a dormência
}

\author{
Anderson Carlos Marafon ${ }^{I}$ Flavio Gilberto Herter ${ }^{I I}$ \\ Fernando José Hawerroth ${ }^{\text {III }}$ Adriana Neutzling Bierhals ${ }^{\text {IV }}$
}

\section{ABSTRACT}

Storage and remobilization are considered key processes for the effective use of nitrogen in temperate fruit trees. As dormancy begins, storage proteins are synthesized, coinciding with a reduction in the levels of free amino acids. Consequently, as dormancy breaks, these storage proteins are degraded, and an increase in the concentrations of amino acids occurs, in order to support new growth. The objective of this study was to evaluate water content of different vegetative tissues (buds, bark, and bole wood), volume of xylem sap, and free amino acid concentrations of xylem sap, during winter dormancy of Hosui Japanese pear trees (VL). Plant material was obtained from the Embrapa Temperate Climate experimental orchard at Pelotas, in the state of Rio Grande do Sul, Brazil. Xylem sap was extracted from the branches with the aid of a vacuum pump, and the free amino acids were determined by gas chromatography, using the EZ kit: Faast GC/FID (Phenomenex). Water content of buds, as well as the volume of sap and concentrations of both aspartic acid and asparagine, substantially increased over time, reaching maximum values in the phase preceding sprouting.

Key words: Pyrus pyrifolia, vascular sap, nitrogenous compounds, sprouting.

\section{RESUMO}

A capacidade de armazenamento e a remobilização de nitrogênio são consideradas processos-chave para o uso eficiente desse macronutriente em plantas frutiferas de clima temperado. Na fase de indução à dormência, ocorre a síntese de proteinas de reserva, coincidindo com a redução nos teores de aminoácidos livres. Entretanto, na fase de superação da dormência, ocorre a degradação dessas proteínas e o aumento nas concentrações de aminoácidos para suprir um novo ciclo de crescimento. O objetivo deste trabalho foi avaliar o conteúdo de água em diferentes tecidos vegetativos (gemas, casca e lenho), o volume de seiva xilemática e suas respectivas concentrações de aminoácidos livres durante $o$ periodo de dormência de pereiras japonesas cv. 'Hosui'. O material vegetal pertence ao pomar experimental da Embrapa Clima Temperado de Pelotas/RS. A seiva do xilema foi extraída dos ramos com auxílio de bomba de vácuo e os aminoácidos livres foram determinados por cromatografia gasosa, utilizando-se o kit EZ: Faast GC/FID (Phenomenex). O conteúdo de água, bem como o volume e as concentrações de ácido aspártico (Asp) e asparagina (Asn) da seiva do xilema aumentaram substancialmente, atingindo valores máximos na fase que antecede a brotação.

Palavras-chave: Pyrus pyrifolia, seiva vascular, compostos nitrogenados, brotação.

\section{INTRODUCTION}

Internal cycling of nitrogen $(\mathrm{N})$ represents an important survival strategy for temperate woody plants, and storage of this nutrient helps ensure the resumption of plant growth after dormancy. It is precisely this storage and remobilization that allows perennial plants to maintain partial independence from the active absorption of $\mathrm{N}$ by the rooting zone (MILLARD, 1996). The few studies that have examined the physiology of temperate woody species have focused on the cycling of $\mathrm{N}$, and most have investigated carbon balance. However, there is increasing evidence regarding the importance of $\mathrm{N}$ storage and remobilization, which are necessary to meet the demands of early growth and development (MILLARD \& GRELET, 2010).

\footnotetext{
'Embrapa Tabuleiros Costeiros, Unidade de Execução de Pesquisa e Desenvolvimento de Rio Largo, 57100-000, Rio Largo, AL, Brasil. E-mail: anderson.marafon@embrapa.br. Corresponding author.

IIDepartamento de Fitotecnia, Universidade Federal de Pelotas (UFPel), Pelotas, RS, Brasil.

IIIEmbrapa Uva e Vinho, Estação Experimental de Fruticultura de Clima Temperado, Vacaria, RS, Brasil.

${ }^{\mathrm{IV}}$ Departamento de Ciências Biológicas, Centro Universitário Cesmac, Maceió, AL, Brasil.
} 
During autumn, deciduous species store $\mathrm{N}$ in the form of storage proteins that are deposited in aerial plant tissues, such as bark and bole wood, as well as in roots (COOKE \& WEIH, 2005). The main mechanism responsible for this storage is the redistribution nutrients, which occurs at the beginning of foliar senescence during autumn. In this process, the proteins of the leaves are hydrolyzed, and the resulting free amino acids are transported via the phloem to storage tissues, where they are converted into reserve proteins. In contrast, the inverse process occurs during the winter, when the hydrolysis of protein reserves (remobilization) produces free amino acids, which are used to meet the demands of new sprouts and inflorescences in the spring (GOMEZ \& FAUROBERT, 2002).

Several studies have observed peaks in the concentration of free amino acids in xylem sap prior to sprouting, and these findings have been attributed to intense remobilization of $\mathrm{N}$ reserves, which serves to sustain the initial growth of sprouts and inflorescences (GLAVAC \& JOCHHEIM, 1993; DONG et al. 2001; MALAGUTI et al., 2001). This increase in amino acid concentration, along with the process of sprouting, occurs as a result of $\mathrm{N}$ remobilization and is dependent on the occurrence of freezing temperatures during dormancy. Low temperatures induce the activity of an endopeptidase, which promotes degradation of storage proteins, producing free amino acids that are then transported via xylem to areas of growth (SAUTER \& VAN CLEVE, 1992).

Remobilization of $\mathrm{N}$ can occur before or simultaneous with absorption from the soil (NIELSEN et al., 2001). Because dormant buds often resume their growth before the rooting zone resumes activity (MALAGUTI et al., 2001), plants need to remobilize the protein reserves that were previously stored during autumn (SAUTER \& VAN CLEVE, 1992). In this manner, the initial growth of buds becomes almost entirely dependent on the $\mathrm{N}$ reserves of vegetative tissues, since the root system is only activated after the initiation of growth by new sprouts. Although few studies have described the dynamics of the process in detail, it is evident that the remobilization of $\mathrm{N}$ occurs before absorption by roots, at least in some species, such as apple (DONG et al., 2001), pear (QUARTIERI et al., 2002), peach (RUFAT \& DeJONG, 2001) and cherry trees (GRASSI et al., 2002). One plausible explanation for the remobilization of $\mathrm{N}$ from vegetative parts before absorption from soil is the fact that air temperature increases more quickly than soil temperature at the beginning of spring, when rates of $\mathrm{N}$ mineralization and availability are still very low (MILLARD \& GRELET, 2010).

In temperate woody species, xylem is considered essential for the translocation of water, ions, nucleotides, and small metabolites such as soluble sugars, as well as nitrogenated organic compounds (TROMP, 2005). Accordingly, the xylem plays a fundamental role in the process of resuming the growth and development by buds after winter dormancy (SAUTER \& VAN CLEVE, 1992). Xylem sap has also been considered the main route for the transport of elements that are needed to break the dormancy of buds (LOESCHER et al., 1990; AMEGLIO et al., 2001) and can therefore serve as a tool for nutritional and physiological studies that investigate the mechanisms of breaking dormancy in deciduous, temperate fruit trees.

The hypothesis tested by this study was that the content of free amino acids and the volume of the xylem from pear trees increase prior to the buds sprouting during winter in the region of Pelotas, Rio Grande do Sul, Brazil. Therefore, the objective was to determine the water content of different aerial tissues (buds, bark, and bole wood), as well as the free amino acid concentrations and volume of xylem sap from branches of pear trees cv. 'Hosui' during dormancy.

\section{MATERIALS AND METHODS}

The study was conducted at the experimental orchard of Embrapa Temperate Climate, in Pelotas, Rio Grande do Sul, Brazil. The climate of the region is classified as Cfa (Köppen), a subtype of humid subtropical climate, with annual averages of $1,582 \mathrm{~mm}$ rainfall, $18.4^{\circ} \mathrm{C}$ air temperature, $78 \%$ relative humidity, and 342 hours of cold $(\mathrm{CH})$ equal to or lower than $7.2^{\circ} \mathrm{C}$ during winter.

For our experiments, it was used fourteenyear-old Japanese pear trees (Pyrus pyrifolia (Burm. f.) Nakai cv. 'Hosui') that had been grafted onto Pyrus calleryana root stocks. The Hosui cultivar requires approximately $721 \quad \mathrm{CH}<7.2^{\circ} \mathrm{C}$ for satisfactory flowering (NISHIMOTO \& FUJISAKI, 1995). As the amount of cold that accumulates in the region of Pelotas is insufficient, a high rate of necrosis occurs in early flowering (NAKASU et al., 1995), but even so, leaf buds and a number of floral buds manage to develop successfully.

In order to obtain the data required for this study, branches from four trees were collected during dormancy, at three points $(8 / 26,9 / 24$ and $10 / 14$ ) between late winter and early spring of 2010 . 
In that year, the accumulated $\mathrm{CH}<7.2^{\circ} \mathrm{C}$ was 389 hours at the first collection $(8 / 26)$ and 451 hours by the second (9/24). At the third collection (10/14), the total $\mathrm{CH}<7.2^{\circ} \mathrm{C}$ remained at 451 hours. By that point, the buds were already at stage C3 (appearance of a green tip), which constitutes the breaking of winter dormancy. After collecting the branches, our evaluations of water content and of the free amino acid concentration and volume of xylem sap were performed at the Plant Physiology Laboratory at Embrapa Temperate Climate.

Water content of the tissues (buds, bark, and bole wood) was calculated from the weights of wet material (WM) and dry material (DM), the latter of which was measured after drying the material in a greenhouse at $70^{\circ} \mathrm{C}$ for 48 hours. From these data, it was calculated the water content (WC), using the formula adopted by CITADIN et al. (2009): WC = (WM-DM)/DM.

Extraction of xylem sap was performed using the methodology described by BOLLARD (1953). Five branches, 30 to $40 \mathrm{~cm}$ long, were collected between 08:00 and 09:00, and 4-cm sections of bark (phloem) were removed from the basal end of the branches, in order to collect only the xylem sap and to avoid its contamination. Branches were embedded in rubber stoppers that had a central orifice and were sealed with parafilm, placed in a Kitasatotype $250 \mathrm{ml}$ flask, and coupled to a vacuum pump (TECNAL TE-058) that applied increasing pressure up to $0.15 \mathrm{MPa}$. Sap was collected in 2-ml microtubes and maintained in ice inside a Kitasato-type flask.

After extracting the sap, dry mass of branches was also determined, in order to calculate the volume of sap per unit dry mass of bole wood $(\mu 1$ $\left.\mathrm{g}^{-1} \mathrm{DM}_{\text {bole }}\right)$, and the volume of the extracted sap was quantified using a reduced volume micropipette.

The extracted sap was stored in a freezer at $-20^{\circ} \mathrm{C}$ and thawed at the time of analysis, which was carried out to determine the concentrations of the free amino acids asparagine (Asn), aspartic acid (Asp), glutamine (Gln), and glutamic acid (Glu). Aliquots $(100 \mu \mathrm{l})$ of sap were analyzed using the EZ kit job: Faast GC/FID (Phenomenex, Torrance, CA, USA).

The separation and quantification of amino acids were performed by gas chromatography (Shimadzu GC 14B) with a Zebron capillary column model ZB-AAA $(10 \mathrm{~m} \times 0.25 \mathrm{~mm})$. Norvaline $(200$ nmol $\mathrm{ml}^{-1}$ ) was used as the internal standard for obtaining a standard chromatogram. Aliquots of $2 \mu 1$ were injected, with an injection temperature of $280^{\circ} \mathrm{C}$, a split rate of $1: 17$, and a detection temperature of $320^{\circ} \mathrm{C}$. The initial oven temperature was $120^{\circ} \mathrm{C}$, with an elevation of $35^{\circ} \mathrm{C} \mathrm{min}$. The column flow was $1.64 \mathrm{ml} \mathrm{min}^{-1}$, and nitrogen gas was used as the carrier under a pressure of $60 \mathrm{KPa}$. The amino acid concentrations were expressed in micrograms per $\mathrm{ml}$ of extracted xylem sap ( $\mu \mathrm{g} \mathrm{ml}^{-1} \mathrm{sap}$ ).

The experimental design was completely randomized, with four replications. Each plant was considered one replication. In the case of water content, a factorial $3 \times 3$ (tissue $\mathrm{x}$ collection date) design was adopted. The averages were compared using the Scott-Knott test, at a 5\% probability level, using the SISVAR statistical software, version 5.6.

\section{RESULTS AND DISCUSSION}

Significant differences were observed in the water content of tissues from the three collections. The water content of the bark (phloem) was higher than that of other tissues at the first (8/26) and second $(9 / 24)$ collections and was higher in both bark and bud tissue at the third collection $(10 / 24)$.

It was noticed that the water content of the bole wood (xylem) decreased significantly in the second collection (9/24) and remained stable until the last collection. A contrary response was observed for the water content of buds, which showed a significant increase at the last collection date (10/14), when the plants were already in the initial phase of budding (stage $\mathrm{C} 3=$ emergence of a green tip). As for the bark, the water content measurements remained similar over time, with no statistical differences between collections. The volume of xylem sap extracted from the branches also showed significant increases over this period, reaching maximum values at the last collection $(10 / 14)$ (Table 1).

In Table 1, it can be observed that the maximum volume of xylem sap $\left(128.21 \mu \mathrm{l} \mathrm{g}^{-1} \mathrm{DM}\right)$ was extracted at the third collection $(10 / 26)$ and that the water content of the bole wood (xylem) was reduced in the last two collections (9/24 and 10/26). These data suggest that, at the first collection, the water that was present in bole wood (xylem) was not in the xylem vessels, but rather in the interfibrillar spaces and the xylem parenchyma cells.

New shoots require nourishment with water, carbohydrates, and nitrogenous organic compounds to develop, and these needs are satisfied as a result of the storage and remobilization of these nutrients (MALAGUTI et al., 2001). It is suggested that the increase in sap volume over the course of dormancy occurred because of the influx of soluble sugars, amino acids, and other metabolites, as well as the concomitant migration of water into the interior of the 
Table 1 - Water content (WC) in tissues and volume of xylem sap ( $\mu \mathrm{g} \mathrm{g}^{-1} \mathrm{DM}_{\text {bole }}$ ) extracted from the branches of Japanese pear trees (Pyrus pyrifolia (Burm. f.) Nakai cv. 'Hosui') during dormancy.

\begin{tabular}{|c|c|c|c|}
\hline \multirow{2}{*}{ Tissue } & \multirow[b]{2}{*}{$26 / 08$} & \multirow[b]{2}{*}{$24 / 09$} & \multirow[b]{2}{*}{$14 / 10$} \\
\hline & & & \\
\hline Buds & $0.82 \mathrm{Cb}$ & $0.92 \mathrm{Bb}$ & $1.67 \mathrm{Aa}$ \\
\hline Bark & $1.57 \mathrm{Aa}$ & $1.68 \mathrm{Aa}$ & $1.57 \mathrm{Aa}$ \\
\hline Bole Wood & $1.12 \mathrm{Ba}$ & $0.87 \mathrm{Bb}$ & $0.92 \mathrm{Bb}$ \\
\hline & --------V & $\left(\mu \mathrm{g}^{-1} \mathrm{D}\right.$ & \\
\hline Bole Wood & $40.45 \mathrm{C}$ & $85.23 \mathrm{~B}$ & $128.21 \mathrm{~A}$ \\
\hline
\end{tabular}

"means followed by the same uppercase letter for data collection, and means followed by the same lowercase letter for tissues, do not differ significantly by the Scott-Knott test $(\mathrm{P}=0.05)$.

xylem vessels, thus increasing the osmotic potential of the sap. The osmotic potential $\left(\Psi_{\mathrm{w}}\right)$ is equal to the inverse of solutes concentration. Therefore, when the solute concentration increases, the osmotic potential decreases (becomes more negative), causing the water to move toward that location.

The increase in the water content of buds indicates rehydration of the tissues, due to the transportation of vascular sap through the xylem vessels, which supply the nutritional and metabolic demands of the buds' meristem tissues. MARAFON et al. (2011) reported that the increase in water content in pear tree buds occurs through migration of water and soluble sugars from the parenchyma cells to the xylem vessels and from the xylem to the buds. Furthermore, ESSIAMAH \& ESCHRICH (1986) found a positive correlation between the dissolution of starch parenchyma and the xylem sap volume of deciduous tree species of northern hemisphere during the spring. AMEGLIO et al. (2001) also reported that low winter temperatures increase the content of soluble sugars in the xylem sap of nut trees, which osmotically directs water from the fibers and parenchyma cells into the xylem.

Concentrations of free amino acids Asn, Asp, Gln, and Glu in the xylem sap showed significant differences over the collections. In the first two collections ( $8 / 26$ and $9 / 24)$, during the initial phase of $\mathrm{N}$ remobilization, the average of the Gln concentrations was higher than that of the other amino acids (Figure 1).

Remobilization in temperate fruit trees has been identified as the main mechanism underlying the supply of $\mathrm{N}$ to new shoots, which may occur before or simultaneous with its absorption byroots (RUFAT \& DeJONG, 2001). In Abbe' Fetel pear trees, for example, remobilization is the predominant source of $\mathrm{N}$, contributing approximately $80 \%$ of total cost of the formation of leaves, flowers, and spurs (TAGLIAVINI et al., 1997).

Free amino acids derived from the hydrolysis of storage proteins are also used in the synthesis of other nitrogenous molecules that are essential to growth (CANTÓN et al., 2005). The data obtained in this study indicate that free amino acids present in xylem vessels are being transported, along with water, to the meristem tissues of buds for the reactivation of their metabolic activity and resumption of growth, in the same way that soluble sugars are derived from starch degradation during winter (MARAFON et al., 2011).

At the last collection (10/14), significant increases in the concentrations of Asp and Asn occurred, reaching values of 291.1 and $224.7 \mu \mathrm{g}$ $\mathrm{ml}^{-1}$, respectively. In this evaluation, the mean concentration of Asp was significantly higher than that of the other amino acids. It was followed by the concentration of Asn, which was also higher than the concentrations of Glu and Gln (Figure 1). Peaks of Asp and Asn concentration demonstrate that the 451 $\mathrm{CH}<7.2^{\circ} \mathrm{C}$ that accumulated during the winter of 2010 was sufficient to cause the hydrolysis of storage proteins and the subsequent supply of essential free amino acids during the process of breaking dormancy.

Similar to the pear trees in our study, the amino acids Asn, Asp, and Gln are prevalent in the xylem sap of apple (Malus domestica Borkh.) (MALAGUTI et al., 2001) and cherry trees (Prunus avium L.) (MILLARD et al., 2006; GRASSI et al., 2002), reaching maximum values near the budding stage. MALAGUTI et al. (2001) reported that, 106 days prior to budding, the concentrations of Asn, Asp, and Gln were 287,109 , and $101 \mu \mathrm{g} \mathrm{ml}^{-1}$ sap, respectively. Using an $\mathrm{N}$ isotope $\left({ }^{15} \mathrm{~N}\right)$, the authors also confirmed 


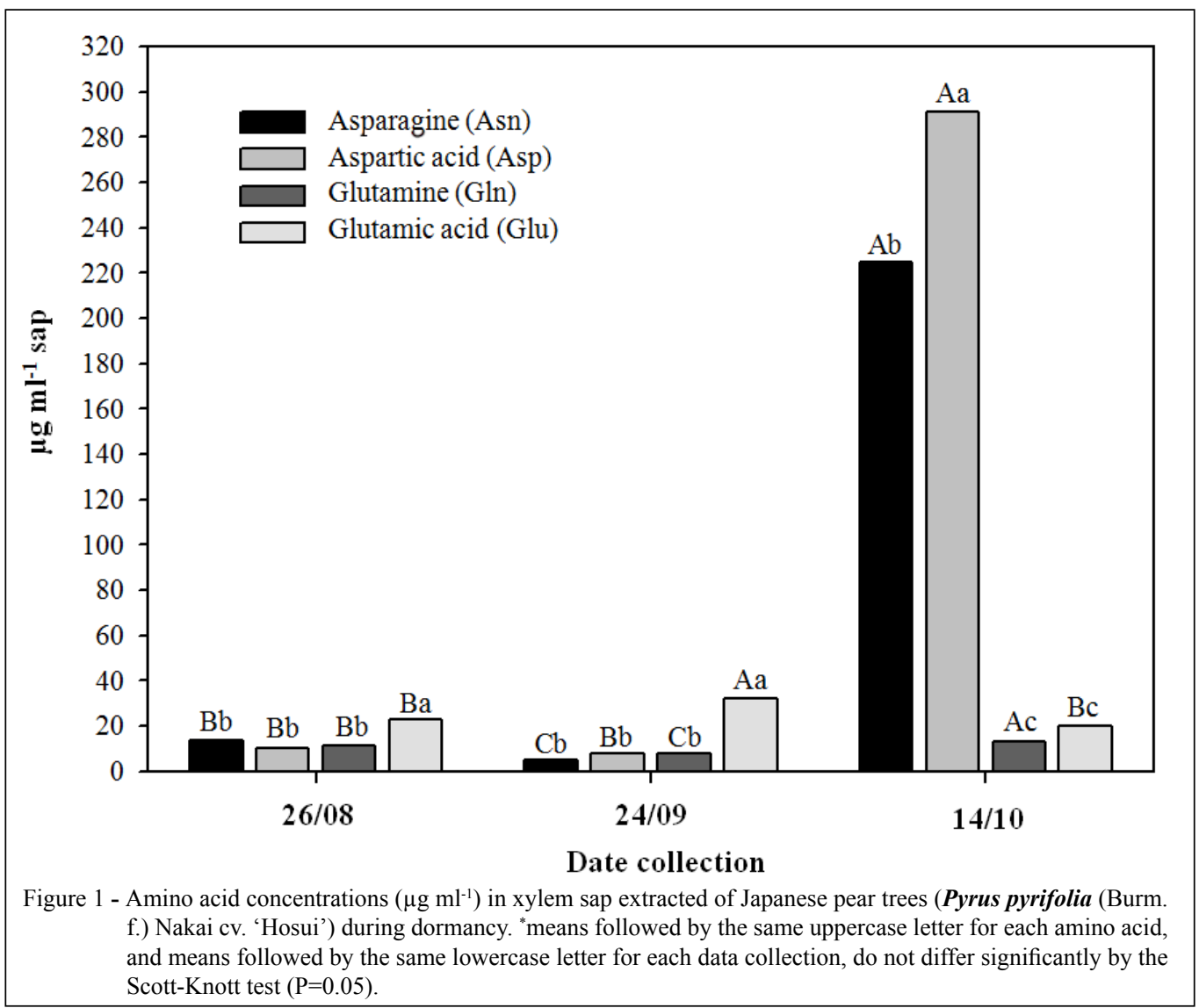

that $\mathrm{N}$ remobilization from the bark and bole wood (xylem) coincided with peaks in the concentrations of the three amino acids in the sap. This finding further supports the hypothesis that the free amino acids reported in the xylem sap of pear trees cv. 'Hosui' are derived from protein reserves in perennial tissues.

In the study carried out by ANDERSEN et al. (1995), it was reported that Asp, Asn, Glu, and arginine (Arg) constitute the highest share of the xylem sap in European pear trees (Pyrus communis). GUAK et al. (2003) also observed that, in apple trees, Asn, Asp, Gln, and Arg concentrations corresponded to $25,36,5$, and $29 \%$ of the total amino acids in the xylem sap, respectively, during the budding stage. Based on the above studies and the data from the present study, it is suggested that concentrations of free amino acids can serve as biochemical markers of the dormancy stage in pear trees.

\section{CONCLUSION}

The water content of the buds, the volume of xylem sap $\left(\mu \mathrm{g} \mathrm{g}^{-1} \mathrm{DM}_{\text {bole }}\right)$, and the concentrations of Asn and Asp $\left(\mu \mathrm{g} \mathrm{ml}^{-1}\right)$ in xylem sap extracted from
Japanese pear tree cv. 'Hosui' branches increased substantially during dormancy and reached maximum values prior to the emergence of the buds, which occurs in early spring.

\section{REFERENCES}

AMEGLIO, T. et al.Winter stem xylem pressure in walnut trees: effects of carbohydrates, cooling and freezing. Tree Physiology, v.21, p.387-394, 2001. Available from: <http://www.ncbi.nlm.nih gov/pubmed/11282578>. Accessed: Mar. 29, 2015. doi: 10.1093/ treephys/21.6.387.

ANDERSEN, P.C. et al. Diurnal variations in tension, osmolarity and the composition of nitrogen and carbon assimilates in xylem fluid of Prunus persica, Vitis hybrid and Pyrus communis. Journal of the American Society of the Horticultural Science, v.120, n.4 p.600-606, 1995. Available from: <http://journal.ashspublications. org/content/120/4/600.full.pdf>. Accessed: Mar. 29, 2015.

BOLLARD, E.G. The use of tracheal sap in the study of appletree nutrition. Journal of Experimental Botany, v.4, n.12, p.363-368, 1953. Available from: <http://jxb.oxfordjournals. org/content/4/3/363.full.pdf $>$. Accessed em: Mar. 29, 2015. doi: $10.1093 / \mathrm{jxb} / 4.3 .363$.

CANTÓN, F.R. et al. Molecular aspects of nitrogen mobilization and recycling in trees. Photosynthesis Research, v.83, p.265- 
278, 2005. Available from: <http://www.ncbi.nlm.nih.gov/ pubmed/16143856>. Accessed: Mar. 29, 2015.

CITADIN, I. et al. Walnut enzyme activity related with carbohydrate mobilization during dormancy period. Revista Brasileira de Fruticultura, v.31, n.2, p.305-313, 2009 Available from: $<$ http://www.scielo.br/scielo.php?pid=S010029452009000200004\&script $=$ sci_arttext $>$. Accessed: Mar. 29, 2015. doi:10.1590/S0100-29452009000200004.

COOKE, J.E.K.; WEIH, M. Nitrogen storage and seasonal nitrogen cycling in Populus: bridging molecular physiology and ecophysiology. New Phytologist, v.167, p.19-30, 2005. Available from: <http://www.ncbi.nlm.nih.gov/pubmed/15948826>. Accessed: Mar. 29, 2015. doi: 10.1093/treephys/tpq042.

DONG, S.F. et al. Soil temperature and plant growth stage influence nitrogen uptake and amino acid concentration of apple during early spring growth. Tree Physiology, v.21, p.541-547, 2001. Available from: <http://www.ncbi.nlm.nih.gov/pubmed/11359712>. Accessed: Mar. 29, 2015. doi: 10.1093/treephys/21.8.541.

ESSIAMAH, S.K.; ESCHRICH, W. Water uptake in deciduous trees during winter and role of conducting tissues in spring reactivation. IAWA Bulletin, v.7, p.1-38, 1986. Available from: <http://booksandjournals. brillonline.com/content/journals/10.1163/22941932-90000435>. Accessed: Mar. 29, 2015. doi: 10.1163/22941932-90000435.

GRASSI, G. et al. Measurement of xylem sap amino acid concentrations in conjunction with whole tree transpiration estimates spring $\mathrm{N}$ remobilization by cherry (Prunus avium L.) trees. Plant, Cell and Environment, v.25, p.1689-1699, 2002. Available from: <http://onlinelibrary.wiley.com/doi/10.1046/ j.1365-3040.2002.00949.x/epdf $>$. Accessed: Mar. 29, 2015. doi: 10.1046/j.1365-3040.2002.00949.x.

GLAVAC, V.; JOCHHEIM, H. A contribution to understanding the internal nitrogen budget of beech (Fagus sylvatica L.). Trees, v.7, p.237-241, 1993. Available from: <http://link.springer.com article/10.1007/BF00202080>. Accessed: Mar. 29, 2015. doi: 10.1007/BF00202080.

GOMEZ, L.; FAUROBERT, M. Contribution of vegetative storage proteins to seasonal nitrogen variations in the young shoots of peach trees (Prunus persica L. Batsch). Journal of Experimental Botany, v.53, p.2431-2439, 2002. Available from: <http://www. ncbi.nlm.nih.gov/pubmed/12432035>. Accessed: Mar. 29, 2015. doi: 10.1016/j.jplph.2010.01.007.

GUAK, S. et al. Determining the role of $\mathrm{N}$ remobilization for growth of apple (Malus domestica Borkh.) trees by measuring xylem-sap N flux. Journal of Experimental Botany, v.54, p.2121-2131, 2003. Available from: <http://www.ncbi.nlm.nih.gov/pubmed/12432035>. Accessed: Mar. 29, 2015. doi: 10.1093/jxb/erg228.

LOESCHER, W.H. et al. Carbohydrate reserves, translocation and storage in woody plant roots. HortScience, v.25, p.274281, 1990. Available from: <http://hortsci.ashspublications.org/ content/25/3/274.full.pdf + html $>$. Accessed: Mar. 29, 2015.

MALAGUTI, D. et al. Translocation of amino acids in the xylem of apple (Malus domestica Borkh.) trees in spring as a consequence of both $\mathrm{N}$ remobilization and root uptake. Journal of Experimental Botany, v.52, p.1665-1671, 2001. Available from: < http://www. ncbi.nlm.nih.gov/pubmed/11479331>. Accessed: Mar. 29, 2015. doi: $10.1093 /$ jexbot $/ 52.361 .1665$.
MARAFON, A.C. et al. Water content in pear tree tissues during the dormancy period under mild winter conditions. Pesquisa Agropecuária Brasileira, v.46, n.9, p.1006-1012, 2011. Available from: <http://seer.sct.embrapa.br/index.php/pab/article/ view/10551>. Accessed: Mar. 29. 2015. doi: 10.1590/S0100204X2011000900006

MILLARD, P. Ecophysiology of the internal cycling of nitrogen for tree growth. Journal of Plant Nutrition and Soil Science, v.159, p.1-10, 1996. Available from: <http://onlinelibrary.wiley. com/doi/10.1002/jpln.1996.3581590102/abstract>. Accessed: Mar. 29, 2015. doi: 10.1002/jpln.1996.3581590102.

MILLARD, P. et al. Translocation of nitrogen in the xylem of field-grown cherry and poplar trees during remobilization. Tree Physiology, v.26, p.527-536,2006. Available from: <http://www. ncbi.nlm.nih.gov/pubmed/16414931>. Accessed: Mar. 29, 2015. doi: $10.1007 / \mathrm{s} 00425-014-2198-8$.

MILLARD, P.; GRELET, G-A. Nitrogen storage and remobilization by trees: ecophysiological relevance in a changing world. Tree Physiology, v.30, p.1083-1095, 2010. Available from: $<$ http://treephys.oxfordjournals.org/content/30/9/1083.abstract $>$. Accessed: Mar. 29, 2015. doi: 10.1093/treephys/tpq042.

NAKASU, B.H. et al. Pear flower bud abortion in southern Brazil. Acta Horticulturae, n.395, p.185-192, 1995. Available from: $<$ http://www.actahort.org/books/395/395 20.htm>. Accessed: Mar. 29, 2015. doi: 10.17660/ActaHortic.1995.395.20

NISHIMOTO, N.; FUJISAKI, M. Chilling requirement of buds of some deciduous fruits grown in southern Japan and the means to break dormancy. Acta Horticulturae, n.395, p.153-160, 1995. Available from: <http://www.actahort.org/ books/395/395 16.htm>. Accessed: Mar. 29, 2015. doi: 10.17660/ ActaHortic.1995.395.16.

QUARTIERI, M. et al. Storage and remobilization of nitrogen by pear (Pyrus communis) trees as affected by timing of $\mathrm{N}$ supply. European Journal of Agronomy, v.17, p.105-110, 2002. Available from: $<$ http://www.sciencedirect.com/science/article/pii/ S1161030101001411>. Accessed: Mar. 29, 2015. doi: 10.1016/ S1161-0301(01)00141-1.

RUFAT, J.; DEJONG, T.M. Estimating seasonal nitrogen dynamics in peach trees in response to nitrogen availability. Tree Physiology, v.21, p.1133-1140, 2001. Available from: <http://treephys. oxfordjournals.org/content/21/15/1133.abstract>. Accessed: Mar. 29, 2015. doi: 10.1093/treephys/21.15.1133.

SAUTER, J.J.; VAN CLEVE, B. Seasonal variation of amino acids in the xylem sap of Populus x canadensis and its relation to protein body mobilization. Trees, v.7, p.26-32, 1992. Available from: <http://link.springer.com/article/10.1007/BF00225228>. Accessed: Mar. 29, 2015. doi: 10.1007/BF00225228.

TAGLIAVINI, M. et al. Remobilised nitrogen and root uptake of nitrate for spring leaf growth, flowers and developing fruits in pear (Pyrus communis L.) trees. Plant and Soil, v.195, p.137-142, 1997. Available from: <http://link.springer.com/article/10.1023/ A\%3A1004207918453>. Accessed: Mar. 29, 2015. doi: 10.1023/A:1004207918453.

TROMP, J. Mineral nutrition. In: TROMP, J. et al. Fundamentals of temperate zone tree fruit production. Leiden: Backhuys, 2005. p.55-64. 